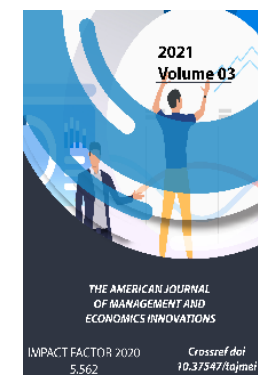

\title{
Socio-Economic Value Of Statistical Study Of Entrepreneurship In The Republic Of Uzbekistan
}

Journal Website:

http://theamericanjour nals.com/index.php/taj mei

Copyright: Original content from this work may be used under the terms of the creative commons attributes 4.0 licence.

\section{Savinova G A.}

Senior Lecturer, Department Of Accounting And Auditing, Ferghana Polytechnic Institute, Uzbekistan

\section{ABSTRACT}

The article discusses the need for a statistical study of entrepreneurship in the Republic of Uzbekistan. The priority areas of statistical research on entrepreneurship are questions of the forms and scale of entrepreneurial activity, investment and innovation activities of entrepreneurs, and the economic efficiency of entrepreneurial processes. The article provides recommendations for improving the focus of statistical research on entrepreneurial activity.

\section{KEYWORDS}

Entrepreneurship, entrepreneurial activity, entrepreneurship statistics, investment activity, "demography" of enterprises, tasks of entrepreneurship statistics.

\section{INTRODUCTION}

One of the functions performed by people in the modern economic system is entrepreneurship. This function is performed by entrepreneurs operating in various sectors of the economy. The concept of entrepreneurship is interpreted in different ways in different sources. Entrepreneurship, as an economic category, is under the jurisdiction of economic, legal, sociological and other sciences $[1,2]$.
The definition of Professor M.G. Nazarov is as follows: "Entrepreneurship is an economic activity aimed at combining living labour with the means of production and other economic assets for the production of goods and services in order to make a profit, as well as activities to provide funds at the disposal of others persons for the purpose of generating income" [3]. 


\section{MATERIALS AND METHODS}

In the Law of the Republic of Uzbekistan "On guarantees of freedom of entrepreneurial activity" dated May 25, 2000, No. 69-II, the following definition of entrepreneurial activity is given: profits) at your own risk and under your property responsibility" [1].

The modern entrepreneur must be entrepreneurial and innovative. At the same time, innovations can be in the field of introducing new equipment and technologies, creating new and improved types of goods, as well as organizational and technical solutions that determine the production and promotion of new technologies and goods to the market. Humanity has entered a new stage in its development - the information society when information and services acquire a higher market value. At this stage, the role of entrepreneurship statistics increases, whose tasks are to collect and process information as the basis for drawing conclusions on the following issues:

- What are the forms and scales of entrepreneurial activity;

- What are the characteristics of investment and innovation activities of entrepreneurs;

- What are the innovative content and economic efficiency of business processes?

In a statistical study of entrepreneurship, we receive information on the number of small enterprises and micro firms, on the number of registered and actually operating private entrepreneurs, on their distribution by forms of ownership, types of economic activity. So, as of January 1, 2021, the number of operating small enterprises and micro firms amounted to 411203.

Small enterprises and micro firms by type of economic activity:

- $\quad$ Trade-131597;

- Industry - 82746;

- Agriculture, forestry and fisheries - 40719;

- Construction - 40695 and others.

In recent years, the number of enterprises with the participation of foreign capital has been growing in Uzbekistan.

The absolute leader in the number of such enterprises in the republic is Tashkent. Tashkent region, as well as Samarkand, Fergana and Surkhandarya, are also in the top five. So, according to the State Statistics Committee, as of April 1, 12,239 enterprises with foreign capital are operating in Uzbekistan: Tashkent $(7,226)$, Tashkent region (1,335), Samarkand (602), Fergana (465), Surkhandarya (458).

The number of business entities operating in the country is 432,458 . Of these, 90,989 (21 per cent) are private enterprises. Tashkent is in the lead here too-12,886 such enterprises operate in the capital. It is followed by the Fergana region (11 131), Kashkadarya (9 509), Namangan (7 209), Surkhandarya (7 188) [4-6].

According to the data of world statistical studies, it is a small business that determines the rate of economic growth, has a significant impact on the employment of the population, on the volume and structure of the gross domestic product of any country. Small business significantly affects the national economy of the country and solves many social problems, especially the problem of unemployment. 
Therefore, the problems of entrepreneurship are given close attention in the Republic of Uzbekistan. On April 21, 2021, the President of Uzbekistan Shavkat Mirziyoyev adopted Resolution No. PP-5087 "On additional measures to improve the entrepreneurship support system, further improve the business climate", which from May 1, 2021, in order to improve business conditions, consistently continue reforms to develop entrepreneurship, expanding mechanisms for supporting entrepreneurship, providing them with the necessary financial and infrastructural resources; additional measures of state support for business entities are being introduced [2].

It is advisable to carry out a statistical study of the effectiveness of entrepreneurial activity by analysing its components, that is, operational and investment activities. The main indicator of the efficiency of operating activities is the level of profitability. Profitability can be calculated using accounting and statistical reporting data. The profitability of goods and services sold, as the ratio of the profit received from the sale of goods and services produced by a given entrepreneur to the cost of these goods and services. Investment activities, in contrast to operating activities, are aimed at taking practical actions in order to obtain profit or another positive effect. It does not always give a quick return, especially if it is associated with the introduction of innovations into the activities of the enterprise.

Most often, an investment project is implemented at the expense of an already existing base of fixed capital, but for an innovative project, the base has to be created. Entrepreneurial activity is characterized by indicators of the "demography" of enterprises - the number of enterprises created and liquidated over a certain period. So, according to the State Statistics Committee, in the country for two months (January-February 2021) 18,565 new business units were added, the growth rate of the number of newly created enterprises, compared to the same period last year, amounted to $107.7 \%$ [3-6].

This information can be obtained from the bodies that carry out state registration of the facts of the creation and liquidation of enterprises. Entrepreneurship statistics are designed to reveal:

- Volume, structure, efficiency of use and rate of change of assets of these enterprises and attracted labour resources;

- The volume of expenditures of resources of enterprises, directions of their use and the results of their activities;

- Indicators of financial activity of enterprises.

Statistical studies allow you to get a holistic picture of the state of entrepreneurial activity, covering various types of economic activities, various industries, types of enterprises.

\section{REFERENCES}

1. Law of the Republic of Uzbekistan "On guarantees of freedom of entrepreneurial activity" dated May 25, 2000 No. 69-II (New edition, approved by the Law of the Republic of Uzbekistan dated May 02, 2012 No. ZRU-328) "Collected Legislation of the Republic of Uzbekistan", 2012, No. 18 , Art. 201.

2. Resolution of the President of the Republic of Uzbekistan Shavkat 
Mirziyoyev No. PP-5087 "On additional measures to improve the business support system, further improve the business climate" National Legislation Database (www.lex.uz), April 22, 2021.

3. M.G. Nazarov. Socio-economic statistics course: Textbook. Moscow. Publishing house OMEGA-L, 2007.987s.

4. James McClave, Terry Sincich Statistics. Textbook. The USA. 2013 p.

5. Hozhaev, A. S. (2017). Voprosy sovershenstvovanija ispol'zovanija statisticheskih issledovanij pri sbore informacii $v$ sfere plodovodstvaovoshhevodstva. Theoretical \& Applied Science, (9), 8-13.

6. Atabaeva, Z. A., \& Khojaev, A. S. (2020). Investment activity and analysis of investment projects. ISJ Theoretical \& Applied Science, 5(85), 714-720. 